DOI: 10.35784/IAPGOS.124

\title{
APPLICATION OF OPTICAL PROFILOMETRY IN THE ANALYSIS OF THE DESTRUCTION PROCESS OF RENOVATION ORGANIC COATINGS FOR THE AUTOMOTIVE INDUSTRY
}

\author{
Konrad Gauda, Kamil Pasierbiewicz \\ University of Economic and Innovation in Lublin, Lublin, Poland
}

Abstract. The article concerns the evaluation of the possibility of using the optical profilometry method in the analysis of the destruction process of acrylic coatings exposed at a climate station in an industrial-urban atmosphere. It was found that the observed changes do not allow to clearly assess the durability of the tested coatings. It seems that the method used may play a supporting role in assessing the quality of the coatings because the surface maps show the number and size of pores in the coating. Therefore, this method can be used, for example, to help determine the optimal parameters of the coating process (e.g. spray pressure).

Keywords: optical profilometer, organic coating, automotive

\section{ZASTOSOWANIE PROFILOMETRII OPTYCZNEJ W ANALIZIE PROCESU DESTRUKCJI RENOWACYJNYCH POWLOK ORGANICZNYCH DLA PRZEMYSLU MOTORYZACYJNEGO}

Streszczenie. Artykut dotyczy oceny możliwości wykorzystania metody profilometrii optycznej w analizie procesu destrukcji renowacyjnych powłok akrylowych przeznaczonych dla przemystu motoryzacyjnego eksponowanych na stacji klimatycznej w atmosferze przemystowo-miejskiej. Stwierdzono, że zaobserwowane zmiany nie pozwalaja jednoznacznie ocenić trwatości badanych powłok. Wydaje się, ze zastosowana metoda może odgrywać role pomocnicza w ocenie jakości powłok, ponieważ mapy powierzchni wyraźnie pokazuja liczbę $i$ wielkość porów w powłoce. Można więc zastosować tę metodę przykładowo jako wspomagająca ustalenie optymalnych parametrów procesu nakładania powłok (np. ciśnienia natrysku).

Slowa kluczowe: profilometr optyczny, powłoka organiczna, motoryzacja

\section{Introduction - outline of optical profilometry method}

The operation of the optical profilometer is based on the principle of light wave interferometry. This means that when the waves of the same frequency and amplitude overlap, a characteristic result wave is created, the amplitude of which depends on the mutual phase shift of the input waves

When both streams are in the amplitude phase, they add up, while when both waves are offset by $180^{\circ}$, a zero amplitude wave is created. This summation and drift property is called interference or superposition and creates a set of dark and bright stripes known as interference fringes when observed on screen or through a microscope [13, 15] (Fig. 1).

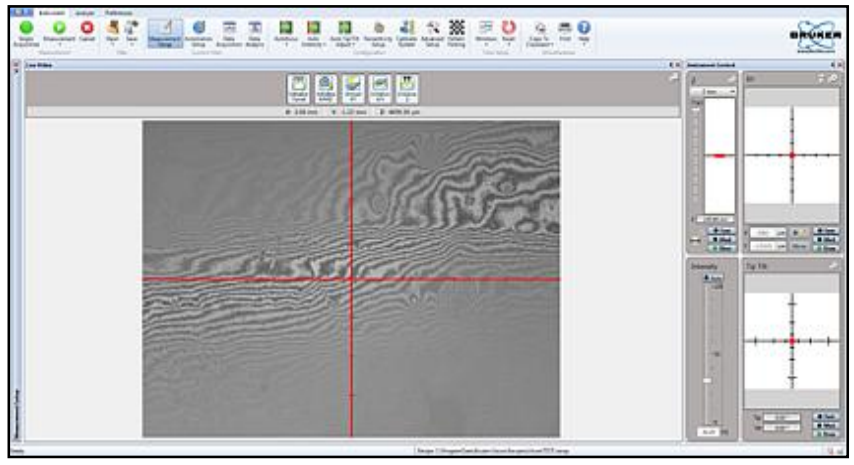

Fig. 1. Interference fringes on the sample surface displayed in Vision 64 application

To use the phenomenon of interference for surface topography analysis, the light beam is divided into two tracks. One of them is undisturbed, while the other one, after reflection from surface irregularities, undergoes phase shifts. After superimposing the disturbed and reference waves, the changes caused by the differences in the height of the tested surface topography can be analyzed.

Figure 2 shows a simplified schematic of the optical profilometer. The wave emitted by the light source is split into two tracks in a special splitter. Each of the beams moves in the direction of the reference mirror and the second mirror, which is the tested surface of the sample. After reflection, phase shifts of the waves are created depending on the distance of the mirrors. Then the reflected beams are put back on each other in the splitter, and the resulting wave is recorded by a detector that measures the intensity of light during sample movement and finds maximum interference.

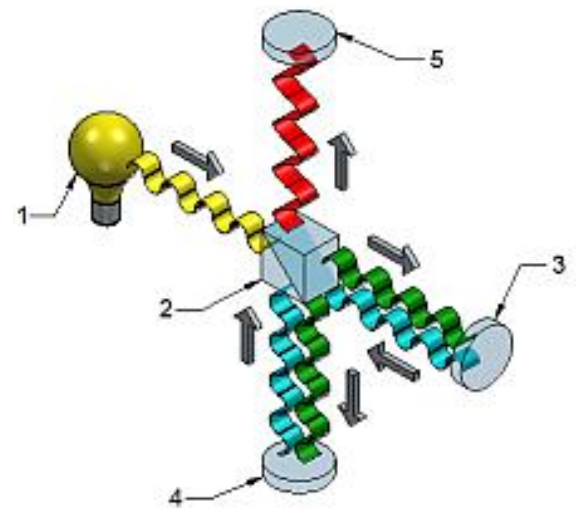

Fig. 2. Simplified diagram of optical interferometer operation [13]: 1-light source 2 - splitter, 3 -reference mirror, 4 -sample tested, 5 -detector

The measurement method, in contrast to the traditional (contact measurement), allows non-contact measurement and achieves accuracy up to $1 \mathrm{~nm}$, which is important for organic coatings testing [1].

\section{Research methodology}

The samples were prepared in accordance with the PN-EN ISO 1514: 2006 standard [11]. Based on the analysis of the literature, standard and the paint materials market, Dupont's organic renovation coatings for the automotive industry based on acrylic resin with the trade designation CS 920 were qualified for testing. Multilayer systems (primer - base varnish - colorless varnish) were applied to steel plates (so-called car body sheet) using the pneumatic spraying method (pressure 7 bar), with the average thickness of a single layer was $50 \mu \mathrm{m}$ [2-5] (Fig. 3).

Samples were labeled with SKxB and SKxC symbols (where: CS-climate station, $\mathrm{x}$ - sample number, $\mathrm{W}$ - white coating (AM1 pigment), $\mathrm{B}$ - black coating (AM5 pigment)). 


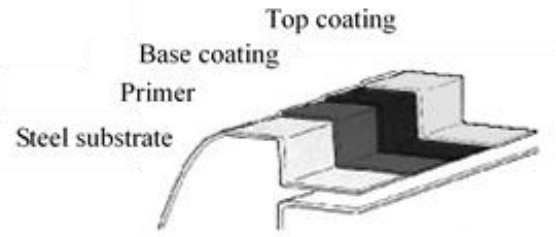

Fig. 3. Multilayer system tested (single layer thickness $50 \pm 5 \mu \mathrm{m}$ )

The samples prepared in this way were analyzed using an optical profilometer, while a Bruker profilometer was used in the tests (Fig. 4).

Using the profilometer, basic surface roughness parameters and their 2/3 D maps were obtained (initial imaging), with several areas of $1 \mathrm{~mm}^{2}$ analyzed (Fig. 5, Fig. 6).

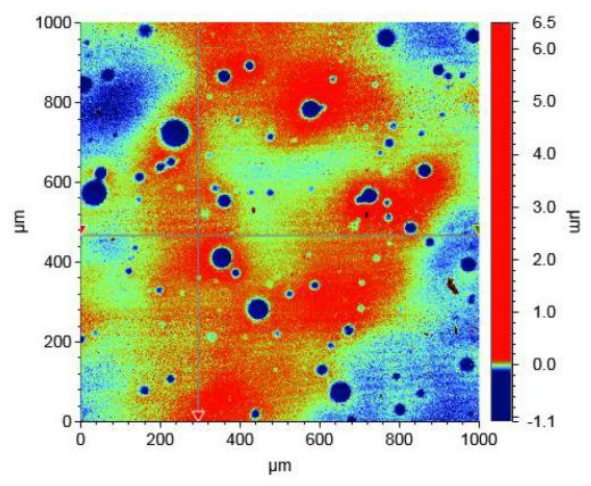

X Profile: $\Delta X=999.4583 \mu \mathrm{m} ; \Delta Z=-0.1099 \mu \mathrm{m}$
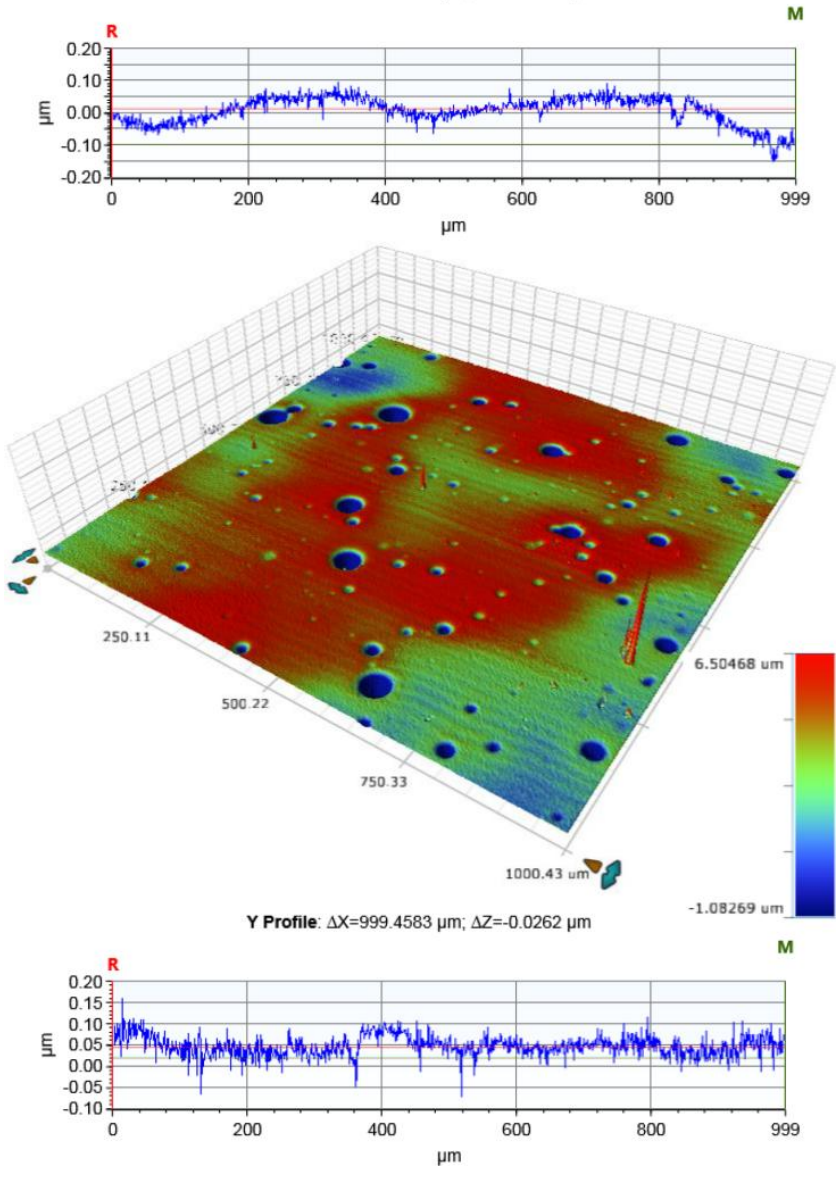

Fig. 5. Preliminary imaging $-2 D / 3 D$ maps and profilograms of sample fragments of the coating surface $-R a=0.053 \mu \mathrm{m}$ (sample CS2 W)
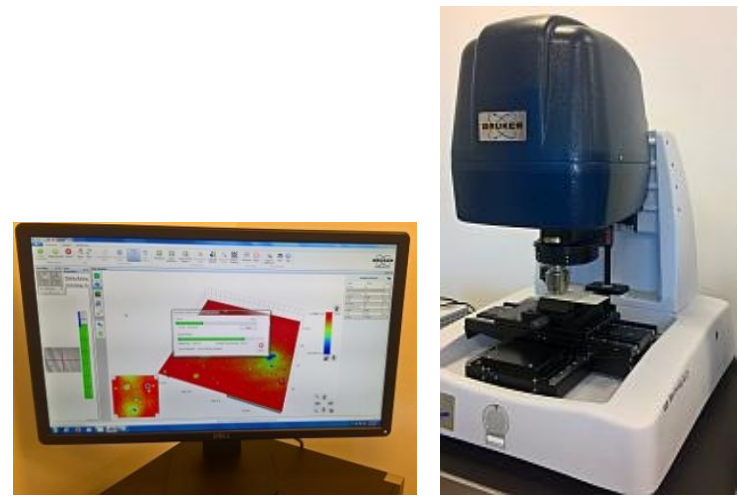

Fig. 4. View of the "Edit Teacher" tool

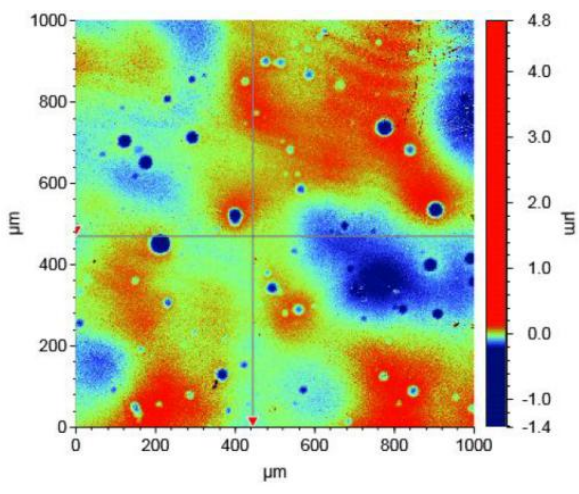

X Profile: $\Delta X=1000.4333 \mu \mathrm{m} ; \Delta Z=-\mu m$ $\mathbf{M}-$
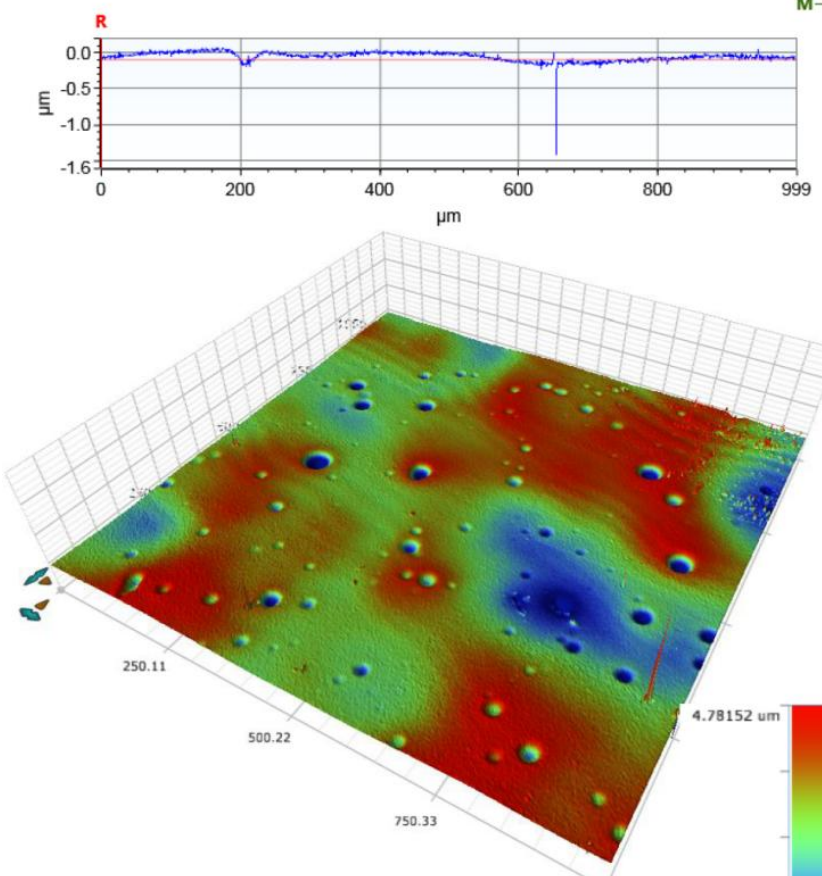

$Y$ Profile: $\Delta X=999.4583 \mu \mathrm{m} ; \Delta Z=0.0997 \mu \mathrm{m}$

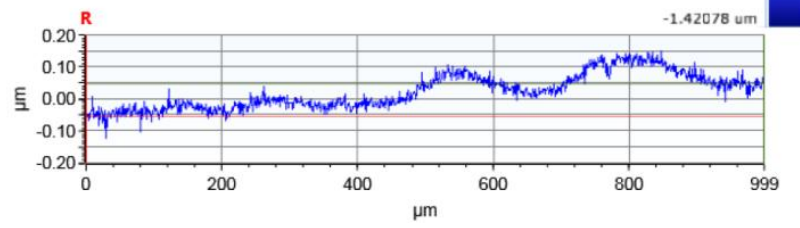

Fig. 6. Preliminary imaging $-2 D / 3 D$ maps and profilograms of sample fragments of the coating surface $-R a=0.064 \mu$ m (sample CS3B) 
Samples with coatings were then exposed at a climate station for 34 weeks in the autumn-winter-spring period in an industrial and urban atmosphere (according to PN-EN ISO 2810: 2005) (Fig. 7) [12].

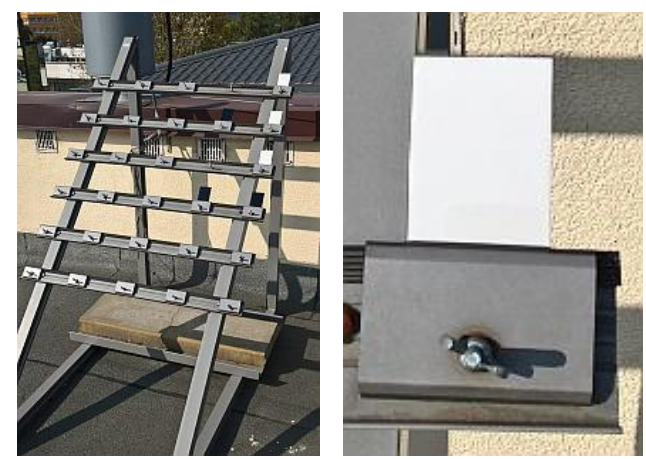

Fig. 7. View of the climate station and method of sample attachment

The average daily temperature during the exposure period was $8.3^{\circ} \mathrm{C}$, humidity $73 \%$, and the amount of precipitation $20.3 \mathrm{~mm}[14]$.
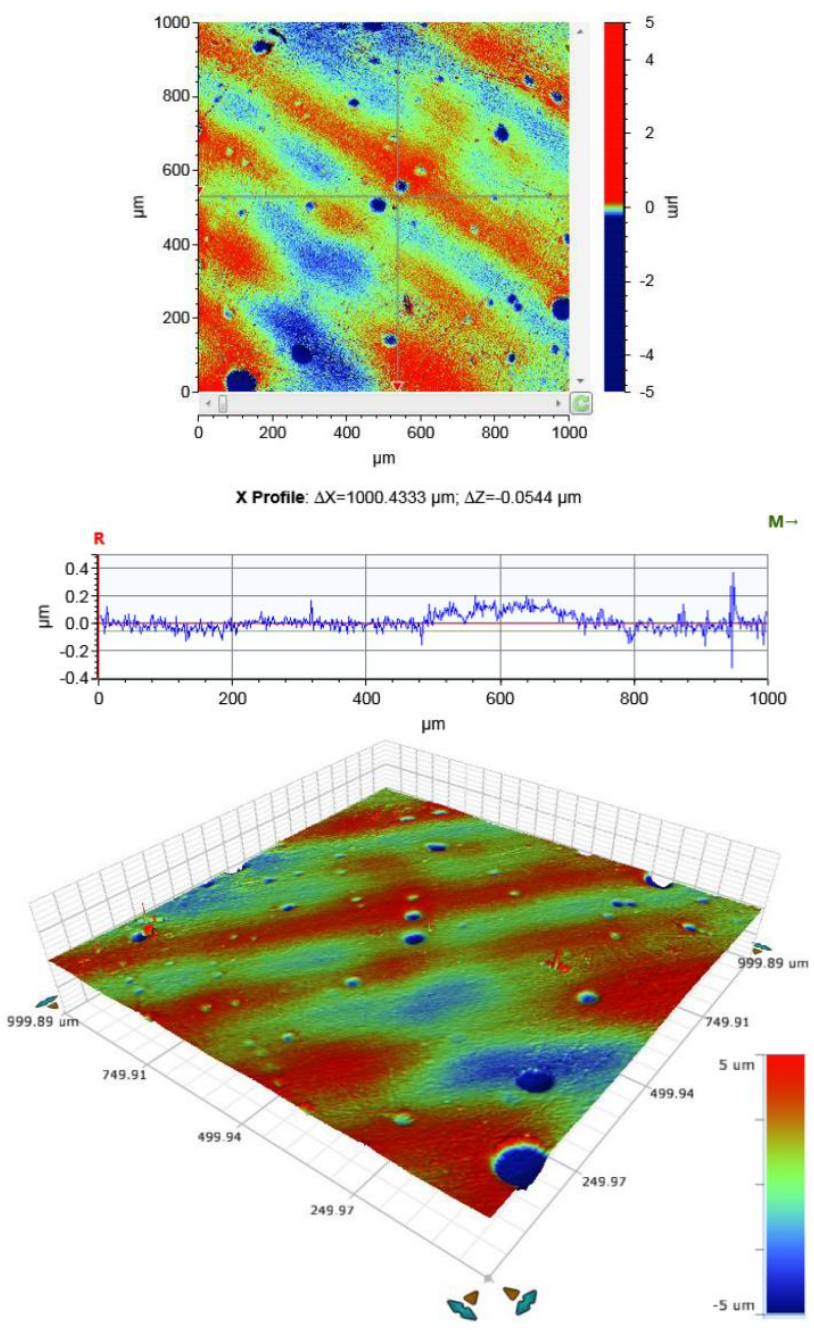

Y Profile: $\Delta X=999.4583 \mu \mathrm{m} ; \Delta Z=-0.1792 \mu \mathrm{m}$

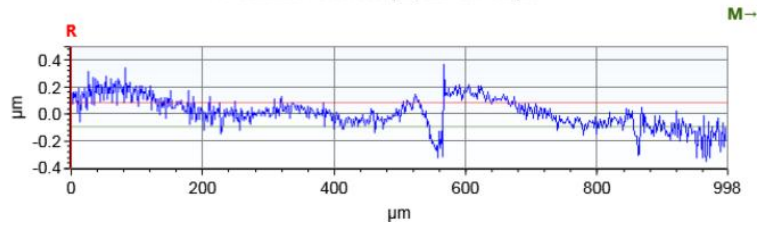

Fig. 8. Final imaging - 2D/3D maps and profilograms of sample fragments of the coating surface $-R a=0.087 \mu m$ (sample CS2W)

\section{Test results}

After the exposure, the surface condition of the coatings was again monitored and the basic roughness parameters were assessed (Fig. 8, Fig. 9, Tab. 1). In order to assess the variability of the $R_{a}$ parameter, a $\mathrm{K}$ factor was introduced, which is a percentage of the ratio of the current value from a given measurement of $y_{n}$ to the initial value of $y_{0}$ described by the following relation (1):

$$
K=\frac{y_{n}}{y_{0}} \cdot 100[\%]
$$

This factor allows the assessment of the degree of change in the Ra parameter of the tested coatings in relation to the initial value obtained at the beginning of the test cycle (coatings before exposure at a climate station - "new").

Table1. Summary of measurement results

\begin{tabular}{|c|c|c|c|c|}
\hline \multirow{3}{*}{ Parameter } & \multicolumn{4}{|c|}{ Multilayer system (average values) } \\
\hline & \multicolumn{2}{|c|}{ white } & \multicolumn{2}{|c|}{ black } \\
\hline & $\begin{array}{c}\text { before } \\
\text { exposure }\end{array}$ & $\begin{array}{c}\text { after } \\
\text { exposure }\end{array}$ & $\begin{array}{c}\text { before } \\
\text { exposure }\end{array}$ & $\begin{array}{c}\text { after } \\
\text { exposure }\end{array}$ \\
\hline $\begin{array}{c}\text { Number of Data } \\
\text { Points [\%] }\end{array}$ & 99.9 & 99.9 & 99.9 & 99.9 \\
\hline $\mathrm{Ra}[\mu \mathrm{m}]$ & 0.053 & 0.087 & 0.072 & 0.134 \\
\hline The K-factor [\%] & \multicolumn{2}{|c|}{164.2} & \multicolumn{2}{|c|}{186.1} \\
\hline
\end{tabular}

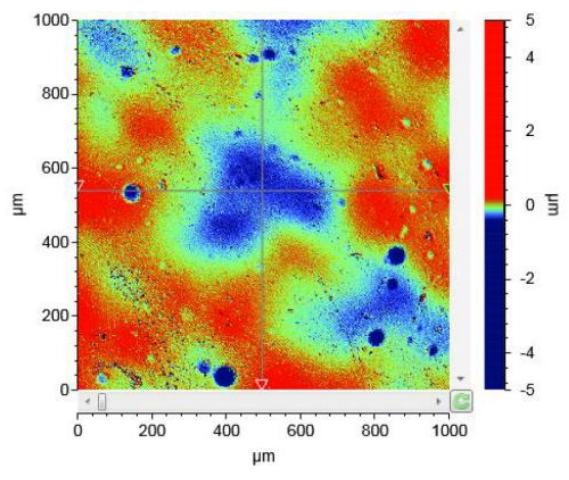

X Profile: $\Delta X=1000.4333 \mu \mathrm{m} ; \Delta Z=-0.0054 \mu \mathrm{m}$
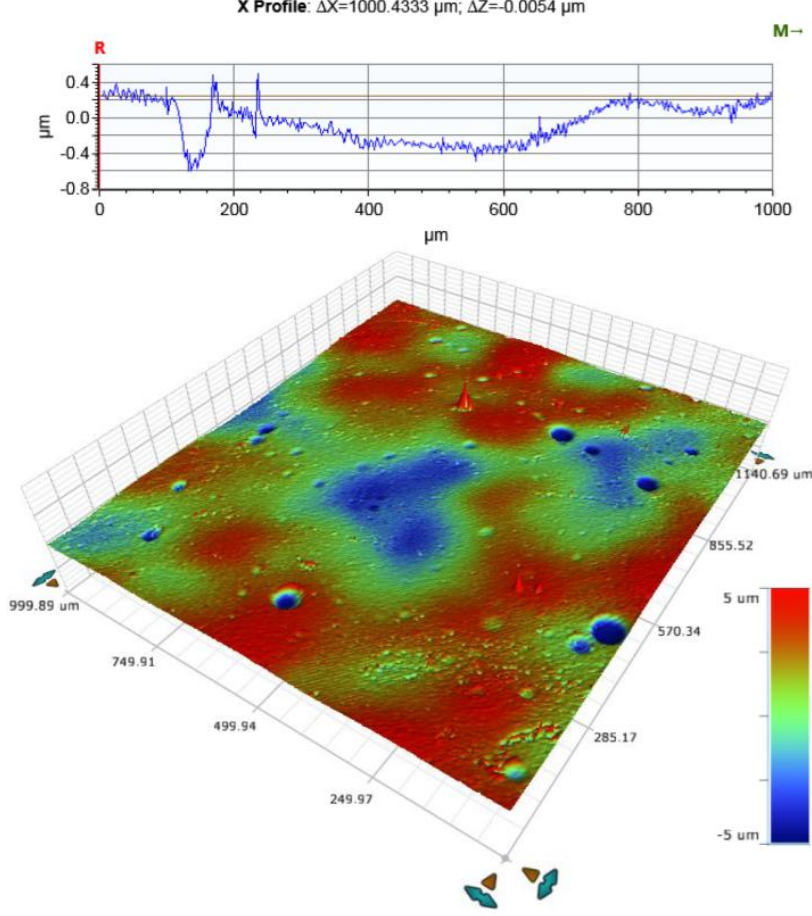

Y Profile: $\Delta X=999.4583 \mu \mathrm{m} ; \Delta Z=-0.3674 \mu \mathrm{m}$

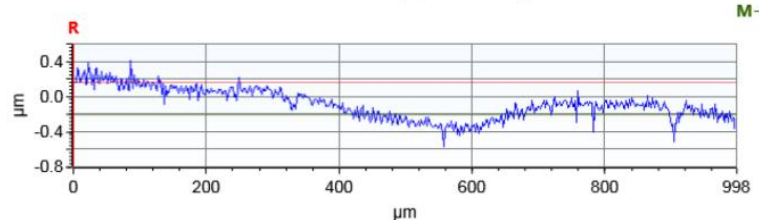

Fig. 9. Final imaging $-2 D / 3 D$ maps and profilograms of sample fragments of the coating surface $-R a=0.127 \mu m$ (sample CS3B) 


\section{Summary}

As a result of the analysis of the obtained images and profilograms of a number of samples, it can be concluded that:

- the sensitivity of the profilometer is most adequate for testing organic coatings - the average number of collected measurement points of the tested surface fragments was over $99.9 \%$, and the measurement accuracy of Ra parameter was $\pm 1 \mathrm{~nm}$,

- no visible differences were found in the obtained surface maps of the coatings before and after exposure - similar size and number of coating pores,

- the value of Ra parameter of the coatings exposed at the climatic station increased, which may indicate the initiation of the destruction process,

- the color of the coating, and thus the type of pigment used may influence the speed of the process of destru - the factor of variation $\mathrm{K}$ for black coatings was $186.1 \%$ and was higher than white coatings by nearly $22 \%$.

Nevertheless, the observed changes do not allow to clearly assess the durability of the tested coatings. The reason for this may be that the exposure time of the samples is too short. Therefore, this time should be extended or intensified by destructive factors using the aging chamber for research, which will be the subject of further studies. An unfavorable factor in this type of research is also the contamination of the coating after the exposure period, which may affect the results [5-8].

It seems that the method used may have an auxiliary/supplementary role in assessing the quality of coatings due to the fact that surface maps clearly show the number and size of pores in the coating. Therefore, this method can be used, for example, as a supporting optimization of the coating process (spray pressure, temperature, drying speed). In the case of determining the durability of coatings, it would be advisable to additionally support the tests of mechanical properties, especially the scratch hardness or adhesion to the substrate, or additionally measure the gloss of the coatings and prepare photographic documentation [3-10].

\section{References}

[1] Dokumentacja techniczna profilometru firmy Bruker (technical documentation)

[2] Gauda K.: Badania korozyjne akrylowych powłok organicznych w komorze solnej. Postępy Nauki i Techniki 15, 2012, 170-179.

[3] Gauda K.: Wodorozcieńczalne powłoki organiczne w przemyśle maszynowym. Monografia. Lubelskie Towarzystwo Naukowe, Lublin 2011.

[4] Gauda K.: Wpływ oddziaływań smaru maszynowego na właściwośc mechaniczne powłok akrylowych o zróżnicowanej zawartości lotnych związków organicznych. Postępy Nauki i Techniki 9, 2011, 145-158.
[5] Gauda K.: Prognozowanie zmian połysku lustrzanego powłok organicznych jako metoda szacowania trwałości pokryć. Postępy Nauki i Techniki 4, 2010, 114-129.

[6] Kotlík P., Doubravová K., Horálek J., Kubáč L., Akrma J.: Acrylic copolymer coatings for protection against UV rays. Journal of Cultural Heritage 15, 2014 $44-48$.

[7] Kotnarowska D., Sirak M.: Destrukcja nawierzchniowych powłok akrylowych starzonych promieniowaniem UV. Autobusy: technika, eksploatacja, systemy transportowe $6(18), 2017,816-821$.

[8] Kotnarowska D., Sirak M.: Wpływ czynników środowiska na destrukcję powłok akrylowych. Ochrona przed Korozją 9, 2017, 300-305.

[9] Lenik K., Gauda K., Lenik Z.: Forecasting of durability of waterborne coatings in the machine industry. Archives of Materials Science and Engineering 37(2), 2009, 102-109.

[10] Pintus V., Wei S., Schreiner M.: Accelerated UV ageing studies of acrylic, alkyd, and polyvinyl acetate paints influence of inorganic pigments. Microchemical Journal 124, 2016, 949-961.

[11] PN-EN ISO 1514:2006 - znormalizowane płytki do badań.

[12] PN-EN ISO 2810:2005 - powłoki w naturalnych warunkach atmosferycznych ekspozycja i ocena.

[13] Patorski K. (ed.).: Interferometria laserowa $\mathrm{z}$ automatyczną analizą obrazu. Wydawnictwo OWPW, Warszawa 2005.

[14] www.meteoblue.com (weather archive for Lublin).

[15] Zhang S.:(ed.).: Handbook of 3D machine vision. Optical metrology and imaging. CRC Press, 2013.

\section{Ph.D. Konrad Gauda}

e-mail: konrad.gauda@wsei.lublin.pl

A graduate of doctoral studies organized at the Faculty of Mechanical Engineering of the Lublin University of Technology. His scientific interests mainly include surface engineering and computer-aided learning process. $\mathrm{He}$ is the author or co-author of 2 monographs and over 30 articles in the field of organic coatings research and the use of computer science in technology and education.

ORCID ID: 0000-0002-7300-6978

\section{M.Sc. Eng. Kamil Pasierbiewicz}

e-mail: kamil.pasierbiewicz@wsei.lublin.pl

Specialist in the field of laboratories devices at the University of Economic and Innovation in Lublin. Ph.D. student at the Lublin University of Technology at the Department of Materials Engineering.
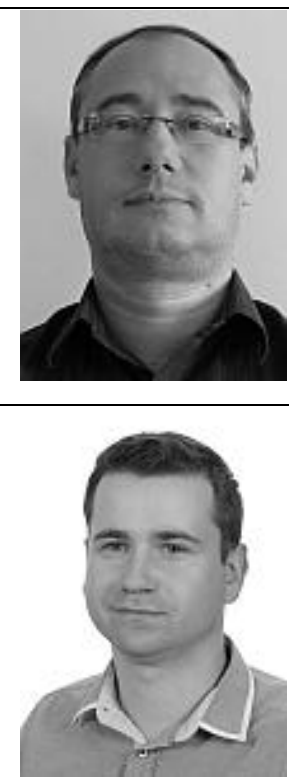

ORCID ID: 0000-0003-4365-7363

otrzymano/received: 10.09.2019 przyjęto do druku/accepted: 06.12 .2019 